\title{
PERAN INDUSTRI RUMAH TANGGA (HOMEINDUSTRY) \\ PADA USAHA KERUPUK TERIGU TERHADAP PENDAPATAN \\ KELUARGA DI KECAMATAN SAKRA KABUPATEN LOMBOK TIMUR
}

\author{
Syahdan \& Husnan \\ STIT Palapa Nusantara Lombok NTB \\ Email: syahdankbr@ymail.com, HP.081803648316
}

\begin{abstract}
ABSTRAK
Penelitian ini merupakan deskriptif untuk melihat gambaran tentang industri ibu rumah tangga (homeindustry) pada usaha kerupuk terigu dan pendapatan keluarga di Kecamatan Sakra Kabupaten Lombok Timur. Populasi berjumlah 279 orang. Pengambilan sampel diambil secara Simple Random Sampling dengan menetapkan dua desa dengan mengambil masing-masing $10 \%$ dari populasi dengan pertimbangan bahwa di dua desa/kelurahan ini cukup banyak terdapat usaha kecil kerupuk terigu. Dari hasil analisis data diperoleh bahwa usaha kerupuk terigu memiliki peran dalam perolehan pendapatan keluarga di Kecamatan Sakra Lombok Timur.Hal ini sesuai dengan hasil pendapatan rata-rata ibu rumah tangga sebesar Rp. 1.110.675/bulan. Ini berarti bahwa pengelolaan industri ibu rumah tangga (homeindustry) pada usaha kerupuk terigu sangat layak untuk dikembangkan agar dapat memberikan rangsangan yang bersifat positif terhadap industri/usaha kecil lain di Kabupaten Lombok Timur khususnya.
\end{abstract}

Kata kunci : industri ibu rumah tangga (homeindustry), pendapatan keluarga

\section{A. PENDAhULUAN}

Dalam Garis-Garis Besar Haluan Negara telah dikemukakan tujuan pembangunan nasional adalah untuk mewujudkan suatu masyarakat yang adil dan makmur merata material dan spiritual berdasarkan Pancasila dan Undang-Undang Dasar 1945, dalam wadah Negara kesatuan Republik Indonesia yang merdeka, 
bersatu dan berkedaulatan rakyat dalam lingkungan pergaulan dunia yang merdeka, bersahabat, tertib dan damai. ${ }^{1}$

Peningkatan perekonomian masyarakat tidak bisa hanya bertumpu pada sektor pertanian semata, namun juga memperhatikan sektor-sektor lain seperti industri, perdagangan, transportasi dan sebagainya. Sektor industri selama ini merupakan salah satu harapan dalam membangkitkan ekonomi masyarakat karena Sektor industri mempunyai pengaruh yang sangat kuat terhadap sektor-sektor lainnya. Bila sektor industri berkembang maka dapat diyakini sektor perdagangan juga akan turut meningkat. Di samping itu sektor industri membutuhkan pasokan bahan baku dari hasil-hasil pertanian maupun dari sektor lainnya termasuk dari hasil sektor industri itu sendiri. Dengan demikian naik turunnya industriakan mempengaruhi pula industry sektor yang lainnya, bahkan peningkatan perindustrian dari tahun ke tahun mengalami kemajuan yang positif, hal ini ditandai dengan semakin banyaknya perusahaan/unit usaha dalam bidang industri ${ }^{2}$.

Provinsi Nusa Tenggara Barat khususnya Kabupaten Lombok Timur ratarata perekonomian masyarakatnya ditunjang padasektor pertanian, sehingga pembangunan pertanian di wilayah NTB ini mendapat prioritas utama, mengingat sebagian besar penduduk NTB (sekitar $60 \%$ )yang tinggal di pedesaan dan bekerja pada sektor pertanian. Sementara untuk Kabupaten Lombok Timur share sektor pertanian berkisar 35-40\% terhadap total PDRB ( 40,25 persen pada tahun 2005), selain itu peranan penting sektor pertanian dalam perekonomian Lombok Timur sangat nyata sebagai tumpuan ekonomi rakyat. Bersamaan dengan upaya pengembangan ekonomi secara komprehensif, hingga saat ini masih sangat diperlukan pemberdayaan masyarakat agar kehidupan sosial ekonomi mereka tidak semakin tertinggal oleh sebagian masyarakat yang telah eksis dalam berbagai kegiatan ekonomi diluar sektor pertanian ${ }^{3}$.

\footnotetext{
${ }^{1}$ Undang-Undang Republik Indonesia Nomor 9 Tahun 1995 Tentang Usaha Kecil

${ }^{2}$ Disperindag Kabupaten Lombok Timur, 2006.

${ }^{3}$ Badan Pusat Statistik, Kabupaten Lombok Timur, 2006 : h. 237
} 
Semakin terbatasnya areal pertanian dan semakin sempitnya rata-rata tingkat kepemilikan lahan untuk usaha pertanian terkait dengan masalah buruh tani, pengangguran musiman, pengangguran teknologi, pengangguran tak kentara, dan mereka yang memiliki tingkat ketergantungan yang tinggi pada keadaan alam dan lingkungan dalam melakukan pekerjaannya. Pengangguran semacam ini merupakan persoalan yang sangat mendasar yang sering dihadapi masyarakat khususnya pada masyarakat pedesaan, karena semakin menyempitnya peluang disekitar pertanian menyebabkan terjadinya penurunan daya serap tenaga kerja di sektor pertanian tersebut ${ }^{4}$.

Menurut Prayitno ${ }^{5}$ Usaha untuk mengatasi permasalahan tenaga kerja perempuan di pedesaan perlu ditindak lanjuti dengan usaha penciptaan industri rumah tangga (homeindustry) yang memiliki kedekatan secara ekonomis dengan produk pertanian dan kedekatan secara sosial dengan tingkat keahlian dan kondisi sosial masyarakat.Pembangunan industri kecil terutama industri yang mengolah hasil pertanian dan mempunyai prospek penting dalam mendukung pembangunan ekonomi pedesaan khususnya untuk menyerap kelebihan tenaga kerja dari sektor pertanian sehingga dapat meningkatkan pendapatan.

Potensi industri pedesaan sebagia besar merupakan industrikecil dan kerajinan rakyat. Peranan keduanya yang menonjol antara lain menggerakkan roda perekonomian desa, mengembangkan prdagangan dan membangun daerah. Dengan demikian potensi yang dimiliki industri kecil perlu dihidupkan, digerakkan dan dikembangkan ditengah-tengah perekonomian moderen agar memiliki keunggulan komparatif atau daya saing dengan produk industri lainnya ${ }^{6}$.

Disamping pembangunan industri rumah tangga (homeindustry)/industri kecil ditujukan untuk meningkatkan dan memperbaiki struktur usaha industri kecil

\footnotetext{
${ }^{4}$ Mulyadi, S. Ekonomi Sumber Daya Manusia Dalam Perspektif Pembangunan, (Jakarta: PT Raja Grafindo Persada.,2003) h. 23

${ }^{5}$ Hadi Prayitno. Pembangunan Ekonomi Pedesaan, (Jakarta: LP3ES, 2987) h. 52

${ }^{6}$ Wirasasmita, Laporan Eksklusif, , (NTB: Baselina Survey, 1993)
} 
kearah yang lebih kuat dan mempunyai daya tumbuh dengan jalan meningkatkan peranan keterkaitan industri kecil dengan sektor industri lain. Oleh karena itu peran industri rumah tangga (homeindustry) yang dilakukan ibu rumah tangga di pedesaan perlu ditangani lebih seksama dan dirangsang pertumbuhannya dalam rangka memperluas kesempatan kerja maupun dalam rangka meningkatkan pendapatan masyarakat.

Untuk mendukung pengembangan industri rumah tangga (homeindustry)/industri kecil, maka pihak pemerintah telah menetapkan suatu kebijaksanaan dengan melakukan pembinaan bagi masyarakat yang melakukan industri kecil tersebut.Industri rumah tangga (homeindustry)/industri kecil ini sangat sesuai untuk dikembangkan di daerah pedesaan, dikarenakan tingkat teknologi yang digunakan sederhana dan dapat menampung msyarakat yang tidak bekerja pada sektor pertanian dan sekaligus untuk menciptakan pemerataan pendapatan untuk memberantas kemiskinan. ${ }^{7}$

Keberadaan industri kecil atau kerajinan rumah tangga (homeindustry) ini menempati peran yang penting dan strategis dalam pembangunan, karena dapat memberikan corak dan warna terhadap usaha-usaha pembangunan pertanian, kepariwisataan, dan tingkat urbanisasi serta meningkatkan pendapatan masyarakat pedesaan sehingga kepincangan pendapatan antara masyarakat pedesaan dan perkotaan dapat diperkecil.

Sementara itu perkembangan Sektor industri di Kabupaten Lombok Timur sampai tahun 2006 dilihat dari sisi keberadaan perusahaan relatif cukup menggembirakan.Selama beberapa tahun ini jumlah perusahaan atau usaha berkembang positif begitu juga dengan penyerapan tenaga kerja. Banyaknya perusahaan atau usaha industri formal tahun 2006 meningkat sebanyak 1.572 unit usaha dibandingkan dengan tahun 2005 sebanyak 1550 unit usaha. Dan banyaknya perusahaan atau usaha industri non formal tahun 2006 meningkat sebanyak 14.783 unit usaha dibandingkan dengan tahun 2005 sebanyak 14.408

\footnotetext{
${ }^{7}$ Hadi Prayitno. Pembangunan Ekonomi Pedesaan, (Jakarta: LP3ES, 2987) h. 52
} 
unit usaha/perusahaan. Peningkatan yang sama juga untuk jumlah tenaga kerja pada perusahaan/usaha industri formal tahun 2006 sebanyak 18.897dibandingkan dengan tahun 2005 sebanyak 14.817, dan jumlah tenaga kerja pada perusahaan non formal pada tahun 2006 sebanyak 42.100 dari jumlah tenaga kerja pada tahun 2005 sebanyak 40.350 tenaga kerja. ${ }^{8}$

Industri rumah tangga (homeindustry) dan kerajinan rakyat di Kabupaten Lombok Timur sebagian besar memiliki kedekatan secara fisik sosial dan ekonomi dengan masyarakat petani yang terdapat di daerah pedesaan. Sebagai satu contoh adalah industri rumah tangga (homeindustry)/industri kecil pembuatan kerupuk yang ada di Kecamatan Sakra pada khususnya, yakni yang terdapat di desa Kabar dan Peresak, dan begitu juga yang tersebar diberbagai daerah di Kabupaten Lombok Timur.

Industri pembuatan krupuk yang dimaksud disini adalah industri rumah tangga (homeindustry)/industri kecil kerupuk terigu dimana industri ini memiliki dan diusahakan oleh masing-masing keluarga dan hanya dikerjakan oleh Ibu rumah tangga. Kebanyakan kegiatan ini dilakukan secara individual mulai dari perolehan bahan baku, proses pembuatan sampai pada pemasaran hasil produksi kerupuk terigu tersebut. Industri kecil kerupuk terigu ini memiliki prospek yang cukup cerah, mengingat bahan baku yang berupa tepung terigu banyak diperoleh di pasar-pasar terdekat yang tidak jauh dari lokasi pembuatan krupuk tersebut. Disamping itu pemasaran hasil industri kecil kerupuk terigu tidaklah sulit, karena selama ini produksi krupuk terigu selalu habis terjual dan masyarakat memiliki minat yang cukup tinggi untuk mengkonsumsi hasil produksi kerupuk terigu ini.

\section{B. KAJIAN PUSTAKA}

\section{Pengertian Industri Kecil/Industri Rumah Tangga (HomeIndustry)}

Industri rumah tangga (homeindustry) atau yang lebih sering diistilahkan industri kecil merupakan suatu usaha mencari manfaat atau faedah bentuk fisik

\footnotetext{
${ }^{8}$ Badan Pusat Statistik, (Lombok Timur Dalam Angka, 2006) h. 30
} 
dari suatu barang sehingga dapat dipergunakan untuk memenuhi kebutuhan dan dikerjakan di rumah. Dalam pengertian ini termasuk juga kegiatan kerajinan tangan.Sehingga industri kecil dapat diartikan sebagai suatu usaha untuk memproduksi dimana didalamnya terdapat perubahan bentuk atau sifat dari suatu barang. Kegiatan industri kecil atau kerajinan rumah tangga umumnya merupakan pekerjaan skunder para petani dan penduduk desa, yang memiliki arti sebagai sumber penghasilan tambahan.Salah satu tujuan industrialisasi daerah pedesaan adalah untuk mengembangkan kegiatan ekonomi daerah tersebut, dan dalam usaha untuk mengembangkan industri kecil dan kerajinan rakyat. Dalam pembangunan industri peranan pemerintah sangat besar sekali manfaatnya. Untuk itu pengarahan, pembinaan, bantuan modal, latihan dan bantuan pembangunan pada sektor industri sangat diharapkan.

Menurut BPS $^{9}$ perusahaan atau usaha industri dapat dikelompokkan menjadi empat kategori berdasarkan pada banyaknya tenaga kerjayang digunakan dari perusahaan yang bersangkutan antara lain :

1. Industri kecil/kerajinan rumah tangga, yakni industri yang jumlah tenaga kerjanya 1-5 orang tenaga kerja.

2. Industri kecil, yakni industri yang jumlah tenaga kerjanya antara 5-19 orang tenaga kerja.

3. Industri sedang, yakni industri yang jumlah tenaga kerjanya antara 20-99 orang tenaga kerja.

4. Industri besar, yakni industri yang jumlah tenaga kerjanya antara 100/lebih tenaga kerja per perusahaan.

Untuk mengetahui lebih jauh pengertian industri kecil ini, maka untuk menumbuh kembangkan industri kecil semacam ini yang biasanya banyak dilakukan didaerah pedesaan maka minimal memerlukan 4 faktor produksi yang terpenting yaitu; faktor produksi modal, faktor produksi alam, tenaga kerja dan kemampuan untuk melakukan kegiatan usaha.

${ }^{9}$ Badan Pusat Statistik, (Lombok Timur Dalam Angka, 2006) h. 30 
Mengenai usaha kecil Departemen Koperasi dan Pembinaan Pengusaha Kecil, sebagaimana yang dirumuskan oleh UU No. 9 tahun 1995 mendefinisikan usaha kecil sebagai berikut ${ }^{10}$ :

1. Usaha yang memiliki kekayaan bersih maksimum Rp. 200 juta tidak termasuk tanah dan bangunan tempat usaha.

2. Hasil penjualan tahunan maksimum Rp. 1 milyar.

3. Milik warga Negara Indonesia.

4. Berdiri sendiri, tidak merupakan anak perusahaan atau cabang perusahaan yang dimiliki, dikuasai atau berafilasi baik langsung maupun tidak langsung dengan usaha menengah atau usaha besar.

Secara umum ciri yang dimiliki sektor usaha kecil antara lain :

1. Sistem pembukuan yang relatif sederhana dan cenderung tidak mengikuti kaidah administrasi pembukuan standar, kadangkala pembukuan tidak diupdate sehingga sukar untuk menilai performance.

2. Margin usaha yang cenderung tipis, mengingat persaingan yang sangat tinggi.

3. Modal terbatas.

4. Pengalaman manajerial yang masih sangat tebatas.

5. Skala ekonomi yang terlalu kecil sehingga sukar mengharapkan untuk mampu menekankan biaya mencapai tingkat efisiensi jangka panjang.

6. Kemampuan pemasaran dan negosiasi serta diversifikasi pasar yang sangat terbatas.

7. Kemampuan untuk memperoleh sumber dana dari pasar modal rendah, mengingat keterbatasan dalam sistem administrasi. Untuk mendapatkan dana di pasar modal sebuah perusahaan harus mengikuti sistem administrasi standar dan transparan.

\section{Upaya Pembinaan dan Pengembangan Usaha Kecil}

Menurut Anoraga ${ }^{11}$ bahwa upaya yang dapat membantu mengembangkan usaha kecil adalah sebagai berikut:

\footnotetext{
${ }^{10}$ Undang Undang No. 9 tahun 1995, Bab 3 Pasal 5
} 
1. Pendekatan makro untuk menciptakan iklim usaha yang kondusif bagi tumbuh dan berkembangnya usaha kecil antara lain meliputi penyediaan barangbarang publik yang lebih berorientasi pada pengembangan usaha kecil seperti fasilitas infrastruktur (sarana transportasi, komunikasi dan lain-lain) kebijakan moneter dan keuangan (misalnya : kredit usaha kecil), fasilitas perpajakan, pendidikan umum, pengembangan teknologi serta kebijakan persaingan yang sehat (fair competition).

2. Menghilangkan monopoli juga menghilangkan kolusi yang mendorong muculnya monopoli. Dengan adanya monopoli ini usaha kecil akan sulit berkembang.

3. Mengembangkan kemitraan antara usaha kecil dengan usaha besar dan didasarkan kedua belah pihak saling menguntungkan, maka kemitraan akan bias turut berlangsung.

4. Usaha kecil juga perlu meningkatkan efisiensi usaha. Hal ini mengingat persaingan usaha semakin tajam terlebih jika akan menembus pasar dunia.

5. Bagi sektor usaha kecil yang belum mempunyai asosiasi perlu dibentuk aosiasi, sedangkan bagi sektor usaha yang sudah ada asosiasinya perlu diperkuat. Hal ini untuk memperkuat usaha kecil dalam bargaining dan persaingan.

Sedangkan menurut Manan dalam Mulyadi ${ }^{12}$ menjelaskan pola pembinaan terhadap industri kecil meliputi :

\section{a. Pembinaan Pelatihan}

Pelatihan merupakan bagian dari pendidikan yang ditujukan kepada perubahan sikap dan keterampilan secara khusus dalam waktu yang relatif singkat. Dengan kata lain, pelatihan merupakan bagian dari pendidikan yang

\footnotetext{
${ }^{11}$ Anoraga, 1996, Pengantar Bisnis Modern, Kajian Dasar Manajemen Perusahaan, (Jakarta: Pustaka Jawa, 1996), h. 22

12 Mulyadi, S. 2003, Ekonomi Sumber Daya Manusia Dalam Perspektif Pembangunan, ( Jakarta: PT Raja Grafindo Persada, 2003), h. 20.
} 
menyangkut proses belajar untuk memperoleh dan meningkatkan keterampilan diluar system pendidikan yang belaku pembinaan pelatihan meliputi aspek keuangan dan modal, teknik produksi dan operasi, sumberdaya manusia (kewirausahaan), pemasaran, manajemen dan teknologi.

\section{b. Pembinaan non Pelatihan}

Pembinaan ini berupa bantuan dan kerjasama baik dari pemerintah atau dariswasta dalam bentuk: 1) bantuan/pemberian dukungan, berupa permodalan, tenaga ahli yang bersifat umum atau manajerial, teknik produksi, dengan pemberian bantuan berupa penyediaan tempat promosi, informasi, penerbitan dan penyebaran katalog, bouklet dan brosur; dan 2) kerjasama, yaitu melakukan pekerjaan bersama-sama dengan mitra usahanya atau perusahaan pembinaan. Bentuk pembinaan dapat berupa kerjasama dagang, kerjasama subkontraktor maupun kerjasama Vendor.

Adapun industri kecil yang dimaksud dalam penelitian ini adalah industri kecil rumah tangga yang terdapat di pedesaan, dimana kegiatan produksi memerlukan keempat faktor produksi modal, alam, tenaga kerja dan kemampuan berusaha. Akan tetapi dari keempat faktor produksi tersebut dua kendala yang dihadapi oleh industri kecil dan rumah tangga di daerah pedesaan yaitu kendala modal dan kemampuan berusaha. Oleh karena itulah disini letak pentingnya peran pemerintah dan organisasi masyarakat setempat dalam memberikan bantuan teknis (khususnya Dinas Perindustrian) agar tingkat pendapatan dan kesejahteraan masyarakat (rumah tangga) mengalami peningkatan.

\section{Usaha Kecil Kerupuk Terigu}

Usaha kecik kerupuk terigu merupakan industri atau usaha lokal yang untuk memperolah baha baku (input) sampai padatingkat pemasarannya dilakukan disekitar daerah tempat industri atau usaha industri itu berkembang. Industri kecil ini tidak berpusat pada satu lokasi industri akan tetapi tesebar dalam beberapa desa dalam satu kecamatan dan dimiliki oleh lebih dari satu orang yang biasanya merupakan industri rumah tangga (home industri). 
Sebagai suatu industri lokal, usaha kecil pembuatan kerupuk terigu ini masih menggunakan peralatan-peralatan dan teknologi yang masih sangat sederhana sehingga pembuatan kerupuk terigu ini sangat mudah dikerjakan dan tidak membutuhkan waktu yang terlalu lama. Dalam proses pembuatan krupuk terigu ini dapat dilakukan melalui tahapan-tahapan sebagai beikut:(1) siapkan bahan-bahan yang akan dipergunakan untuk memnbuat kerupuk terigu selengkap mungkin; (2) masukkan tepung terigu ke dalam ember plastik ukuran besar/baik, dan soda ke dalam ember plastik ukuran besar/bak, kemudian campurkan sesuai dengan ketentuan, masukkan bumbu-bumbu yang sesuai dengan keinginan sehingga menciptakan cita rasa yang enak nantinya; (3) kemudian masukkan air sesuai dengan ukuran tepung terigukedalam ember plastik besar, lalu aduk sampai merata sehingga tepung benar-benar menyampur dengan bumbu-bumbunya; 4) setelah bahan-bahan yang dicampur sudah merata, kemudian adonan dimasukkan kedalam plastik pembungkus; (5) setelah proses pembungkusan selesai, masukkan plastik pembungkus yang sudah diisi satu persatu kedalam panci besar yang sudah berisi air untuk direbus; (6) dalam perebusan ini airnya harus benar-benar mendidih dan adonannya harus benar-benar matang, kemudian setelah matang tunggu lagi adonan sampai betul-betul dingin; (7) sesudah itu dilakukan pemotong (iris tipis), dengan pisau pengiris lalu diletakkan di tempat yang telah disediakan; (8) setelah semua adonan selesai dipotong (pengirisan), kemudian dijemur sampai betul-betul kering (waktu yang dibutuhkan untuk proses pengeringan ini maksimal 3 hari sehingga kerupuk benar-benar kering); (9) apabila semua kerupuknya sudah benar-benar kering kemudian digoreng dengan minyak penggoreng sampai matang lalu diangkat dengan saringan, titiskan 1-2 menit; (10) setelah proses penggorengan selesai barulah dinamakan kerupuk terigu, kemudian dinginkan dulu baru setelah itu dibungkus dengan plastik pembungkusnya; dan (11) kerupuk yang sudah dibungkus siap untuk segera dipasarkan. 


\section{Pengertian Tenaga Kerja}

Menurut Mulyadi ${ }^{13}$ yang dimaksud dengan tenaga kerja adalah penduduk dalam usia kerja 15- 64 tahun yang secara potensial dapat bekerja. Dengan kata lain bahwa tenaga kerja adalah jumlah seluruh penduduk dalam suatu Negara yang dapat memproduksi barang dan jasa jika ada permintaan terhadap tenaga mereka, dan jika mereka mau berpartisipasi dalam aktivitas tersebut. Adapun angkatan kerja (labour force) adalah bagian dari tenaga kerja yang sesungguhnya terlibat, atau berusaha untuk terlibat dalam kegiatan produktif yaitu produksi barang dan jasa.

\section{a. Pengertian Tenaga Kerja Perempuan}

Partisipasi tenaga kerja perempuan dapat disebabkan oleh beberapa hal, dibidang pertanian sejak awal dalam memenuhi kebutuhan pokoknya tenaga kerja wanita dibutuhkan untuk menambah tenaga yang ada. Dengan berkembangnya industri (teknologi) yang artinya tersedianya pekerjaan yang cocok bagi perempuan, maka terbukalah kesempatan meningkatnya partisipasi tenaga kerja. Akan tetapi masalah kehidupan yang semakin sulit terlebih-lebih pada keluarga yang tidak mampu mendorong wanita lebih banyak bekerja mencari nafkah. Hal ini ditandai dengan semakin meningkatnya jumlah tenaga kerja wanita yang tersebar untuk mengisi lowongan pekerjaan baik yang terdapat di perkotaan maupun daerah pedesaan dan penigkatan ini terlihat nyata dari tahun ketahun.

Menurut Sedijoprapto ${ }^{14}$ (1982) mengemukakan bahwa motif-motif yang mendorong perempuan untuk bekerja diluar rumah adalah: (1) karena keharusan dengan ekonomi; (2) karena didorong adanya keinginan membentuk karir dan (3) karena dalam pembangunan diperlukan tenaga kerja dan wanita merupakan sumber daya manusia.

Perkembangan ekonomi dan sosial tidak boleh tidak akan menimbulkan disintegrasi pembagian kerja diantara laki-laki dan perempuan yang secara tradisional terbentuk di desa dan di kota, begitu pula dengan tingkat upah yang

\footnotetext{
${ }^{13}$ Mulyadi, S. 2003, Ekonomi Sumber Daya Manusia Dalam Perspektif Pembangunan, ( Jakarta: PT Raja Grafindo Persada, 2003), h. 30.

${ }^{14}$ Sedijoprapto. E, Tenaga Kerja Wanita Indonesia, Suatu Tinjauan Literatur, (Jakarta: PDIN - LIPI, 1982).
} 
didapatkan karena produktifitas yang dihasilkan antara pekerja laki-laki dan perempuan tidak sama sekalipun antara kaum laki-laki dan perempuan usia atau tingkatan pendidikannya sama ${ }^{15}$.

\section{b. Pengertian Ibu Rumah Tangga}

Selain pekerjaan sebagai ibu rumah tangga yang kegiatannya bekerja didalam rumah (mengerjakan pekerjaan rumah), ibu rumah tangga juga dapat melakukan kegiatan-kegiatan lain sebagai penunjang dan pengisi waktu luang, baik itu kegiatan yang dilakukan diluar maupun didalam rumah, dalam hal ini misalnya yang sesuai dengan penelitian ini yakni ibu rumah tangga yang bekerja membuat kerupuk terigu dimana kegiatan ini merupakan usaha kecil miliknya, sehingga dengan kegiatan memproduksi kerupuk ini dapat membantu menambah pendpatan rumah tangga.

Ibu rumah tangga adalah seorang yang dalam pekejaannya sebenarnya sangat berperan dalam memberikan nilai tambah didalam suatu keluarga, akan tetapi seorang ibu rumah tangga tidak terlalu disorot sebagai penambah pendapatan keluarga dimana pendapatan ibu rumah tangga ini merupakan suatu pekerjaan yang lazim dilakukan oleh ibu rumah tangga dalam satu keluarga, karena pada hakekatnya kegiatan mencari nafkah tidak hanya dibebankan kepada seorang suami akan tetapi merupakan kewajiban juga bagi seorang istri/ibu rumah tangga selama kegiatan tersebut bisa menambah pendapatan keluarga.

\section{Pola Curahan Tenaga Kerja/Alokasi Waktu}

Pada saat musim tanam padi, responden ikut membantu suaminya bekrja di sawah yaitu menanam padi. Pekerjaan ini dilakukan setalah ibu rumah tangga selesai mengerjakan pekerjaan rumah tangganya. Sedangkan kegiatan untuk membuat kerupuk terigu ini, responden mengerjakannya pada pagi hari sekitar jam 09.00 sampai jam 12.00 wita, sore hari sekitar jam 15.00 sampai jam 18.00 wita dan pada malam harinya sekitar jam 20.00 sampai jam 22.00 wita (Hasil wawancara dengan responden).

${ }^{15}$ Afrida BR. MS, Ekonomi Sumber Daya Manusia, (Jakarta: Galia Indonesia, 2003). 
Dalam penelitian ini tenaga kerja perempuan yang dimaksud adalah tenaga ibu rumah tangga yang bekerja dan membuat kerupuk terigu atau pemilik usaha kerupuk terigu itu sendiri dimana mereka berstatus sebagai ibu rumah tangga biasa bersuamikan para petani yang pekerjaan tetapnya adalah menjalankan usaha tani dengan kepemilikan lahan pertanian yang relatif sempit.

Secara deskriptif curahan waktu ibu rumah tangga dapat diklasifikasikan menjadi 3 macam kegiatan pekerjaan antara lain; (1) kegiatan pekerjaan mencari nafkah dalam usaha kerupuk terigu; (2) kegiatan pekerjaan rumah tangga; dan (3) kegiatan lain-lain (termasuk ibadah, istirahat dan lain-lain).

\section{METODE PENELITIAN}

Penelitian ini menggunakan metode dekriptif. metode diskriptif ini digunakan untuk mengetahuiperan industri rumah tangga (homeindustry) pada usaha kerupuk terigu yang berada di kecamatan Sakra Kabupaten Lombok Timur. Populasi dalam penelitian ini sebanyak 279 orang yang berasal dari kelurahan Pancor berjumlah 62 orang dan Kelayu berjumlah 217 orang. Pengambilan sampel dilakukan secararandom sampling dengan mengambil $10 \%$ dari masingmasing populasi sehingga jumlah sampelnya berjumlah 28 orang.

Teknik pengumpulan data dalam penelitian ini adalah wawancara, observasi, dokumentasi, survey, dan studi kepustakaan. Jenis data pada penelitian ini adalah data primer mengenai jumlah produksi, harga jual hasil produksi, pendapatan responden dan data-data yang berhubungan dengan penelitian ini. Sedangkan data skunder mengenai data dari Badan Pusat Statistik, Dinas Pertambangan dan Industri, dan Dinas Tenaga Kerja dan Transimigrasi Kabupaten Lombok Timur.

Teknik yang digunakan dalam menganalisis data adalah analisis kuantitatif mengenai peran industri rumah tangga (homeindustry) terhadap perolehan pendapatan ibu rumah tangga dalam membuat kerupuk terigu. Untuk analisis 
besarnya tingkat pendapatan ibu rumah tangga dari usaha kecil kerupuk terigu menggunakan rumus :

$$
\begin{aligned}
& \mathrm{NR}=\mathrm{TR}-\mathrm{TC} \\
& \mathrm{TR}=\mathrm{P} \times \mathrm{Q} \\
& \bar{y}=\frac{N R}{N}
\end{aligned}
$$

Keterangan :

$\mathrm{NR}=$ Pendapatan bersih yang diterima dari hasil produksi di seluruh responden.

$\mathrm{TR}=$ Pendapatan kotor yang diterima dari hasil produksi di seluruh responden

$\mathrm{TC}=$ Biaya total yang dikeluarkan untuk produksi oleh semua responden

$\mathrm{P}=$ Harga kerupuk terigu (harga perbungkus kerupuk terigu/perunit)

$\mathrm{Q}=$ Jumlah barang/hasil kerupuk terigu yang dijual.

$\bar{y}=$ pendapatan rata-rata bersih semua responden

\section{HASIL DAN PEMBAHASAN}

\section{Analisis Pembiayaan}

Dalam proses pemasarannya, selain disekitar lokasi pembuatan kerupuk terigu itu sendiri responden juga memasarkan hasil produksinya ke pasar menggunakan alat transportasi (menggunakan bemo atau becak/dokar dan sepeda motor). Dalam sehari responden mengeluarkan biaya transportasi rata-rata $\mathrm{Rp}$. 5.000 per hari (pulang pergi). Jadi, biaya tiap bulannya sebesar Rp. 150.000, sehingga total biaya untuk seluruh responden (28 orang) sebesar 4.200.000.

Dalam melakukan kegiatan produksi pembuatan kerupuk terigu ini dengan mempekerjakan ibu-ibu rumah tangga disesuaikan dengan jumlah bahan baku pembuatan kerupuk terigu perhari dan dibantu oleh anggota keluarganya. Adapun biaya tenaga kerja tiap responden (28 orang) dalam memproduksi dengan rincian pada tabel sebagai berikut: 


\begin{tabular}{|c|c|c|c|}
\hline No. & Jumlah Bahan Baku & \multicolumn{2}{|c|}{\begin{tabular}{c} 
Biaya Produksi (Rp) \\
\cline { 3 - 4 }
\end{tabular}} \\
\cline { 3 - 4 } & 10 & Perhari & Perbulan (30 hari) \\
\hline 1. & 15 & 14.000 & 420.000 \\
\hline 2. & 25 & 24.000 & 720.000 \\
\hline 3. & 34.000 & 1.020 .000 \\
\hline
\end{tabular}

Namun dalam penelitian ini hanya dilakukan pada jumlah bahan baku yang berjumlah $15 \mathrm{Kg}$.

Sementara biaya variabel (Variabel Cost) dan biaya tetap (Fixed Cost) berdasarkan besar kecilnya jumlah produksi yang dihasilkan. Adapun biaya variabel yang dikeluarkan terdiri dari tepung terigu, minyak goreng, bahan bakar (kayu bakar), bumbu, plastik pembungkus dan soda.

Berikut besarnya biaya variabel (Variabel Cost) yang dikeluarkan oleh responden dapat dilihat pada tabel di bawah ini.

\begin{tabular}{|r|l|c|r|r|}
\hline No. & \multicolumn{1}{|c|}{ Jenis Bahan } & Jumlah Fisik & \multicolumn{1}{c|}{ Nilai (Rp.) } & \multicolumn{1}{c|}{$\begin{array}{c}\text { Nilai Rata-rata } \\
\text { (Rp.) }\end{array}$} \\
\hline 1 & Tepung terigu & $10.480 \mathrm{~kg}$. & 68.120 .000 & 2.432 .857 \\
\hline 2 & Minyak goreng & $5.028 \mathrm{~kg}$. & 60.336 .000 & 2.154 .857 \\
\hline 3 & Bahan bakar/kayu bakar & 2.256 ikat & 11.280 .000 & 402.857 \\
\hline 4 & Bumbu-bumbu & 640 bgks. & 1.920 .000 & 68.571 \\
\hline 5 & Plastik pembungkus & 1.470 gulung & 10.290 .000 & 367.500 \\
\hline 6 & Soda & 1.555 bgks. & 8.085 .000 & 288.750 \\
\hline \multicolumn{2}{|c|}{ Jumlah } & & $\mathbf{1 6 0 . 0 3 1 . 0 0 0}$ & $\mathbf{5 . 7 1 5 . 3 9 3}$ \\
\hline
\end{tabular}

Sedangkan besarnya biaya tetap (Fixed Cost) berupa peralatan produksi seperti panci (tempat merebus bahan-bahan yang sudah dibungkus dengan plastik pembungkus), penggorengan, ember plastik (bak untuk mencampur aduk), penyaring/saringan, alat pemotong/pisau, dan alat penjemur (sasak: kelabang). Biaya-biaya masing-masing alat tersebut dapat dilihat pada tabel di bawah ini.

\begin{tabular}{|c|l|r|r|}
\hline No. & \multicolumn{1}{|c|}{ Jenis Peralatan } & Nilai Penyusutan (Rp.) & $\begin{array}{c}\text { Nilai Rata-rata } \\
\text { Penyusutan (Rp.) }\end{array}$ \\
\hline 1 & Panci & 90.000 & 3.214 \\
\hline
\end{tabular}




\begin{tabular}{|c|l|r|r|}
\hline 2 & Penggorengan & 64.000 & 2.286 \\
\hline 3 & Bak/ember plastik & 37.500 & 1.339 \\
\hline 4 & Saringan/penyaring & 46.000 & 1.643 \\
\hline 5 & Pisau & 20.750 & 741 \\
\hline 6 & Penjemur/Kelabang & 151.840 & 5.423 \\
\hline \multicolumn{2}{r|}{ Jumlah } & $\mathbf{4 1 0 . 0 9 0}$ & $\mathbf{1 4 . 6 4 6}$ \\
\hline
\end{tabular}

Berdasarkan tabel di atas, maka secara keseluruhan total biaya produksi (biaya variabel, biaya tetap, dan biaya tenaga kerja dan biaya transportasi) yang dikeluarkan oleh responden yang bekerja pada industri kecil pembuatan kerupuk terigu yakni :

$$
\begin{aligned}
\text { TC } & =\text { TFC }+ \text { TVC } \\
& =410.090+160.031 .000+19.700 .000+4.200 .000=184.341 .090
\end{aligned}
$$

Adapun rincian total biaya produksi krupuk terigu untuk seluruh responden (28 orang) dapat dilhat pada tabel dibawah ini.

\begin{tabular}{|c|l|r|r|}
\hline No. & Jenis Biaya & \multicolumn{1}{|c|}{ Total Biaya (Rp.) } & Rata-rata Biaya (Rp.) \\
\hline 1 & Biaya variabel & 160.031 .000 & 5.715 .393 \\
\hline 2 & Biaya tetap & 410.090 & 14.646 \\
\hline 3 & Biaya tenaga kerja & 19.700 .000 & 703.572 \\
\hline 4 & Biaya transportasi & 4.200 .000 & 150.000 \\
\hline \multicolumn{2}{|c|}{ Jumlah } & $\mathbf{1 8 4 . 3 4 1 . 0 9 0}$ & $\mathbf{6 . 5 8 0 . 6 1 0}$ \\
\hline
\end{tabular}

\section{Analisis Pendapatan}

Pendapatan yang dimaksud disini adalah pendapatan yang diperoleh oleh ibu rumah tangga dari usaha kecil pembuatan kerupuk terigu di daerah penelitian. Pendapatan ibu rumah tangga ini terdiri dari pendapatan kotor (total produksi dikalikan dengan tingkat harga produksi per unit) dan pendapatan bersih (pendapatan kotor dikurangi dengan total biaya-biaya produksi)

Pendapatan ibu rumah tangga dari hasil usaha kerupuk terigu ini dapat dilihat pada tabel berikut :

\begin{tabular}{|c|c|c|c|}
\hline No. & Keterangan & Rumus & $\begin{array}{c}\text { Jumlah hasil } \\
\text { Produksi (Rp.) }\end{array}$ \\
\hline
\end{tabular}




\begin{tabular}{|c|l|c|r|}
\hline 1. & Pendapatan kotor & $\begin{array}{c}T R=P X Q= \\
430.880 \times \mathrm{Rp} .500\end{array}$ & 215.440 .000 \\
\hline 2. & Total biaya & TC $=$ TFC + TVC & 184.341 .090 \\
\hline 3. & Pendapatan bersih & $\begin{array}{c}N R=T R-T C= \\
215.440 .000-184.341 .090\end{array}$ & 31.098 .910 \\
\hline 4. & $\begin{array}{l}\text { Rata-rata pendapatan } \\
\text { responden }\end{array}$ & $\begin{array}{c}-- \\
y\end{array}$ & $\frac{N R}{N}$ \\
& & $\frac{31.098 .910}{28}$ & 1.110 .675 \\
\hline
\end{tabular}

\section{Hubungan tingkat pendapatan ibu rumah tangga terhadap pendapatan keluarga}

Kegiatan usaha kecil pembuatan kerupuk terigu yang berada di Kecamatan Sakra (Desa Kabar dan Peresak) Kabupaten Lombok Timur ini merupakan kegiatan usaha kecil yang cukup efektif bagi masyarakat khususnya ibu rumah tangga, karena usaha semacam ini tidak terlalu sulit untuk dilakukan, ketersediaan input yang terdapat di pedesaan sehingga usaha ini sangat bagus untuk dikembangkan sebagai upaya meningkatkan pendapatan. Untuk mengetahui besarnya pendapatan ibu rumah tangga dan pendapatan kepala keluarga dapat dilihat pada tabel berikut :

\begin{tabular}{|c|r|r|r|}
\hline $\begin{array}{c}\text { No. } \\
\text { Resp. }\end{array}$ & $\begin{array}{c}\text { Pendapatan Ibu } \\
\text { Rumah Tangga }\end{array}$ & \multicolumn{2}{|c|}{$\begin{array}{c}\text { Pendapatan Kepala } \\
\text { Keluarga }\end{array}$} \\
\hline 1 & 1.570 .580 & 450 & \multicolumn{1}{l|}{ Total } \\
\hline 2 & 1.147 .950 & 450 & 1.597 .950 \\
\hline 3 & 1.147 .950 & 500 & 1.647 .950 \\
\hline 4 & 1.147 .950 & 750 & 1.897 .950 \\
\hline 5 & 1.570 .580 & 600 & 2.170 .580 \\
\hline 6 & 1.151 .750 & 600 & 1.751 .750 \\
\hline 7 & 1.570 .580 & 450 & 2.020 .580 \\
\hline 8 & 655.58 & 1.000 .000 & 1.655 .580 \\
\hline
\end{tabular}




\begin{tabular}{|c|c|c|c|}
\hline 9 & 1.147 .950 & 500 & 1.647 .950 \\
\hline 10 & 1.147 .950 & 600 & 1.747 .950 \\
\hline 11 & 1.570 .580 & 500 & 2.070 .580 \\
\hline 12 & 1.151 .750 & 800 & 1.951 .750 \\
\hline 13 & 1.570 .580 & 350 & 1.920 .580 \\
\hline 14 & 655.58 & 1.100 .000 & 1.755 .580 \\
\hline 15 & 1.147 .950 & 450 & 1.597 .950 \\
\hline 16 & 654.58 & 900 & 1.554 .580 \\
\hline 17 & 1.148 .950 & 750 & 1.898 .950 \\
\hline 18 & 1.571 .580 & 600 & 2.171 .580 \\
\hline 19 & 654.58 & 1.200 .000 & 1.854 .580 \\
\hline 20 & 1.571 .580 & 500 & 2.071 .580 \\
\hline 21 & 654.58 & 450 & 1.104 .580 \\
\hline 22 & 1.148 .950 & 450 & 1.598 .950 \\
\hline 23 & 654.58 & 1.000 .000 & 1.654 .580 \\
\hline 24 & 1.570 .580 & 500 & 2.070 .580 \\
\hline 25 & 655.58 & 900 & 1.555 .580 \\
\hline 26 & 1.147 .950 & 720 & 1.867 .950 \\
\hline 27 & 655.58 & 1.000 .000 & 1.655 .580 \\
\hline 28 & 655.58 & 500 & 1.155 .580 \\
\hline Jumlah & 31.099 .910 & 17.920 .000 & 49.669 .910 \\
\hline
\end{tabular}

\section{E. PENUTUP}

\section{Kesimpulan}

Dari uraian yang terdapat di atas maka dapat disimpulkan bahwa rata-rata tingkat pendapatan ibu rumah tangga yang melakukan usaha kerupuk terigu ini cukup besar sehingga dapat membantu dan menambah pendapatan keluarga, yaitu sebesar Rp. 1.110.675 yang merupakan pendapatan bersih setiap bulannya. 
Dari hasil perhitungan analisis tersebut di atas dapat disimpulkan bahwa tingkat pendapatan ibu rumah tangga yang meakukan usaha kerupuk terigu ini mempunyai peran signifikan terhadap peningkatan pendapatan keluarga.

\section{Saran}

a. Pengembangan industri kecil (homeindustry) ini menjadi contoh bagi usaha industri kecil lainnya agar segala bentuk usaha kecil yang ada di Lombok Timur ini menjadi lebih berkembang sehingga bisa menciptakan lapangan pekerjaan bagi masyarakat.

b. Hendaknya ada kerja sama antara tenaga kerja perempuan (ibu rumah tangga) dan pihak pemerintah baik permodalan maupun dalam usaha kecil lainnyaagar usaha yang dilakukan dapat menjadi lebih baik dan menguntungkan.

\section{F. REFRENSI}

Afrida BR. MS. 2003, Ekonomi Sumber Daya Manusia, Galia Indonesia.

Anoraga, 1996, Pengantar Bisnis Modern, Kajian Dasar Manajemen Perusahaan, Pustaka Jawa, Jakarta.

Badan Pusat Statistik, Kabupaten Lombok Timur Dalam Angka, tahun 2006.

Hadi Prayitno, 1987. Pembangunan Ekonomi Pedesaan, LP3ES, Jakarta.

Mardikanto, 1990,Wanita dan Keluarga, PT Tritunggal Tata Pajar, Surakarta.

Mulyadi, S. 2003, Ekonomi Sumber Daya Manusia Dalam Perspektif Pembangunan, PT Raja Grafindo Persada.

P. Joko Subagyo. 2006, Metode Penelitian Dalam Teori dan Praktek, PT. Rineka Cipta , Jakarta.

Sedijoprapto. E, 1982, Tenaga Kerja Wanita Indonesia, Suatu Tinjauan Literatur, PDIN - LIPI, Jakarta.

Teguh, Moh. 2005, Metodologi Penelitian Ekonomi Teori dan Aplikasi, PT. Raja Grafindo Persada, Jakarta.

Wardatul Hayati, Etos Kerja Pedagang Pindang Desa Rumbuk Kecamatan Sakra Kabupaten Lombok Timur (Tinjauan Sejarah Sosio Ekonomi), Tahun 2004, Skripsi STKIP Hamzanwadi Selong.

Wirasasmita, 1993, Laporan Eksklusif, Baselina Survey, NTB. 